\title{
Transmission of Cryptotaenia japonica Witches' Broom and Onion Yellows Phytoplasmas by Hishimonus sellatus Uhler*
}

\author{
Norio Nishimura**, Satoshi NAKAJIMA**, Toshimi SAWAYAnAGi***, \\ Shigetou NAMBA***, Toshiki SHIOMI ${ }^{\dagger, t}$, Izumi MATSUDA ${ }^{\dagger}$ \\ and Tsuneo TsUCHIZAKI**
}

Key words : Cryptotaenia japonica witches' broom phytoplasma, onion yellows phytoplasma, Hishimonus sellatus, insect transmission.

Mycoplasma-like organisms (MLOs) cause hundreds of diseases in a variety of crops and trees that are of agricultural importance worldwide. However, little progress has been made in the classification of these organisms because of the lack of effective techniques for identifying or differentiating these pathogens. A recent phylogenetic analysis of MLOs using 16S rRNA gene sequences showed that MLOs are a diverse group containing no less than six distinct 16S rRNA gene clades $^{7)}$. Based on this phylogenetic information, the name "phytoplasma" was proposed for these organisms.

In Japan, phytoplasma isolates classified in the $16 \mathrm{~S}$ rRNA Group I phytoplasmas ${ }^{7)}$ are known to be transmitted by Macrosteles striifrons Anufriew, Hishimonus sellatus Uhler or Hishimonoides sellatiformis Ishihara. $H$. sellatus and $H$. sellatiformis both transmit mulberry dwarf phytoplasma (MD-P) ${ }^{1,2}$, one of the Group I phytoplasmas. $M$. striifrons transmits other Group I phytoplasmas, including onion yellows $(\mathrm{OY}-\mathrm{P})^{5}$, Cryptotaenia japonica witches' broom (CJW-P) ${ }^{8}$, eggplant dwarf ${ }^{4)}$, lettuce yellows ${ }^{9)}$ and tomato yellows phytoplasmas ${ }^{3)}$. However, the transmissibility of $M$. striifrons-borne phytoplasmas by either $H$. sellatus or $H$. sellatiformis and of $H$. sellatus-borne phytoplasmas by $M$. striifrons has not been examined. That the vector insects are heterologous within a single phytoplasma group is very interesting. We therefore, tried to transmit CJW-P, OY-P and MD-P independently using heterologous leafhopper vectors. In this paper we report that $M$. striifrons-borne phytoplasmas can also be transmitted by $H$. sellatus.

Phytoplasma isolates An OY-P isolate was obtained in Saga Prefecture in 1982 from onions (Allium cepa L.) with leaf chlorosis and stunted growth with fasciculation. OY-P was maintained on garland chrysanthemum (Chrysanthemum coronarium cv. Satoyutaka) in a greenhouse by inoculation using $M$. striifrons. CJW-P was obtained in Ibaraki Prefecture in 1995 from $C$. japonica having generalized chlorosis and stunted growth, with the production of thin secondary shoots. The infected plants eventually died. CJW-P has been maintained on $C$. japonica cv. Yanagawa in a greenhouse by inoculation using $M$. striifrons. MD-P was collected in Ibaraki Prefecture in 1994, from mulberry trees (Morus spp.) that showed dwarfing of shoots and leaves. MD-P has been maintained on mulberry seedlings (cv. Ichinose) in a greenhouse by sequential inoculations using $H$. sellatus.

Vector insects Adult $M$. striifrons collected from C. japonica fields were confined in a cage with rice plants (Oryza sativa cv. Kinuhikari). Rice is not a host for either CJW-P or OY-P. After the first generation nymphs appeared, the adults were removed from the cage. When the first generation matured, the adults, which did not carry any agent that would infect $C$. japonica or garland chrysanthemum, were transferred from the rice plants to healthy $C$. japonica or garland chrysanthemum plants. Similarly, $H$. sellatus adults collected from mulberry fields were confined in a cage with a healthy mulberry plant. After the first generation nymphs appeared, the adults were removed from the cage. These nymphs, which did not carry any agents that would infect mulberry plants, were transferred to other healthy mulberry plants.

Transmission tests of CJW-P and OY-P by $H$. sellatus Non-infective $H$. sellatus adults were given 3 to 7 days of acquisition access feeding to $C$. japonica plants infected with CJW-P or garland chrysanthemum plants infected with OY-P. The leafhoppers were maintained on healthy mulberry plants for three weeks to fulfill the latent period and then were given an inoculation access feeding to healthy mulberry, C. japonica or

* This work was partly supported by PROBRAIN.

** Koibuchi College of Agriculture, Uchihara-machi, Ibaraki 319-0323, Japan＼cjkstart鯉淵学園

*** Graduate School of Agricultural and Life Sciences, The University of Tokyo, Bunkyo-ku, Tokyo 113-0023, Japan 東京大学大学院農学生命科学研究科

† National Agriculture Research Center, Tsukuba 305-0856, Japan＼cjkstart農業研究センター

I† Present address : National Institute of Agro-Environmental Science, Tsukuba 305-0856, Japan 
garland chrysanthemum plants for 3 to 7 days. Ten to 50 insects were obliged to feed on each plant for the inoculation. Four of 156 C. japonica plants inoculated with CJW-P developed symptoms. Three of 24 mulberry plants became infected with CJW-P and developed yellowing. Fourteen of 18 garland chrysanthemum plants and three of $16 C$. japonica plants, both of which were inoculated with OY-P, showed symptoms (Table 1). For controls, $H$. sellatus adults were maintained on healthy mulberry plants and not exposed to diseased plants. Ten to 20 adults each were confined with a garland chrysanthemum, C. japonica or mulberry plant. Ten plants each were' used for the mock inoculation. These plants remained healthy for more than two months after the end of the feeding period.

Transmission tests of CJW-P and OY-P by $M$. striifrons Non-infective $M$. striifrons adults were given an acquisition access feeding to $C$. japonica plants infected with CJW-P or garland chrysanthemum plants infected with OY-P for 5 to 7 days. Twenty-four of $60 C$. japonica plants inoculated with CJW-P and 31 of 35 garland chrysanthemum plants inoculated with OY-P developed symptoms (Table 1). Again, for controls $M$. striifrons adults were maintained on rice plants without exposure to diseased plants. Ten adults were each confined with a garland chrysanthemum plant for the mock inoculation. The control plants remained healthy for more than 2 months after the end of the feeding period.

Transmission tests of MD-P to garland chrysanthemum plants by $\boldsymbol{H}$. sellatus $H$. sellatus adults were allowed an acquisition access feeding on MD-P infected mulberry plants. Following the latent period expected for MD-P, five to 10 adults were allowed an inoculation access feeding for 3 to 7 days on garland chrysanthemum plants (cv. Satoakira, Satoyutaka and Kiwame) (Table 2). A month after the inoculation feeding, many of the inoculated garland chrysanthemum plants showed shoot-tip stunting and leaf yellowing typical of MD-P infection. The results suggest that MD-P can be transmitted to garland chrysanthemum plants by $H$. sellatus and that the mode of transmission of $H$. sellatus-borne MD-P is basically similar to that of $H$. sellatus for $M$. striifrons-borne CJW-P and OY-P. This is the first report of infection of garland chrysanthemum plants by MD-P.

Transmission tests of MD-P by M. striifrons Non-infective $M$. striifrons adults were given an acquisition access feeding to MD-P infected plants. They were left on mulberry plants for 2 to 3 days and on garland chrysanthemum plants for 6 days. Then, these leafhoppers were maintained on healthy rice plants for at least 3 weeks. Leafhoppers were subsequently given an inoculation access feeding to mulberry plants or C. japonica plants for 7 days or to garland chrysanthemum plants for 2 to 7 days (Table 3). Two to 30 leafhoppers were fed on each plant in the inoculation. However, none of the plants that had been inoculated with MD-P developed symptoms (Table 3 ).

Detection of $\boldsymbol{O Y}-\boldsymbol{P}$ and $\boldsymbol{C J W}-\boldsymbol{P}$ by PCR PCR was performed using both a universal primer set (SN910601 and SN910502) and a phytoplasma-specific primer set (SN910601 and SN910204) with DNA extracted from test plants or leafhoppers ${ }^{6}$. Preparation of total DNA from plants and leafhoppers and PCR amplification were carried out using previously described procedures $^{6)}$. PCR was performed on two of 14 garland

Table 1. Transmission of Cryptotaenia japonica witches' broom phytoplasma (CJW-P) and onion yellows phytoplasma (OY-P) by $H$. sellatus and $M$. striifrons

\begin{tabular}{|c|c|c|c|c|c|}
\hline Phytoplasma & Leafhopper & $\begin{array}{l}\text { Acquisition feeding } \\
\text { period }\end{array}$ & Inoculated plants & $\begin{array}{c}\text { No. of inoculated } \\
\text { plants }\end{array}$ & $\begin{array}{l}\text { No. of infected } \\
\text { plants }\end{array}$ \\
\hline \multirow[t]{6}{*}{ CJW-P } & \multirow[t]{5}{*}{ H. sellatus } & \multirow[t]{2}{*}{3 days } & C. japonica & 86 & 4 \\
\hline & & & Morus spp. & 19 & 2 \\
\hline & & \multirow[t]{2}{*}{5} & C. japonica & 30 & 0 \\
\hline & & & $M$. spp. & 5 & 1 \\
\hline & & 7 & C. japonica & 40 & 0 \\
\hline & M. striifrons & $5-7$ & C. japonica & 60 & 24 \\
\hline \multirow[t]{3}{*}{ OY-P } & \multirow[t]{2}{*}{ H. sellatus } & \multirow[t]{2}{*}{3} & C. japonica & 16 & 3 \\
\hline & & & C. coronarium & 18 & 14 \\
\hline & M. striifrons & $3-7$ & C. coronarium & 35 & 31 \\
\hline
\end{tabular}

Table 2. Transmission of mulberry dwarf phytoplasma (MD-P) to garland chrysanthemum plants by H. sellatus

\begin{tabular}{lcclrc}
\hline \hline Phytoplasma & Leafhopper & $\begin{array}{c}\text { Acquisition feeding } \\
\text { period }\end{array}$ & \multicolumn{1}{c}{ Inoculated plants (cv.) } & $\begin{array}{c}\text { No. of inoculated } \\
\text { plants }\end{array}$ & $\begin{array}{c}\text { No. of infected } \\
\text { plants }\end{array}$ \\
\hline MD-P & H. sellatus & 3 days & C. coronarium cv. Satoakira & 18 & 18 \\
& & $7-8$ & C. coronarium cv. Satoyutaka & 5 & 1 \\
& & & C. coronarium cv. Kiwame & 5 & 4 \\
\hline
\end{tabular}


Table 3. Transmission tests of mulberry dwarf phytoplasma (MD-P) by M. striifrons

\begin{tabular}{lclcc}
\hline \hline MD-P source plants & $\begin{array}{c}\text { Acquisition feeding } \\
\text { period }\end{array}$ & $\begin{array}{c}\text { Inoculated } \\
\text { plants }\end{array}$ & $\begin{array}{c}\text { No. of inoculated } \\
\text { plants }\end{array}$ & $\begin{array}{c}\text { No. of infected } \\
\text { plants }\end{array}$ \\
\hline Morus spp. & $2-3$ days & M. spp. & 12 & 0 \\
M. spp. & 2 & C. japonica & 40 & 0 \\
M. spp. & 2 & C. coronarium & 5 & 0 \\
C. coronarium & 6 & C. coronarium & 7 & 0 \\
\hline
\end{tabular}

Table 4. Detection by PCR of Cryptotaenia japonica witches' broom phytoplasma (CJW-P) and onion yellows phytoplasma (OY-P) from $H$. sellatus that were previously given an acquisition feeding to CJW-P or OY-P infected plants

\begin{tabular}{lcccc}
\hline \hline Phytoplasma & $\begin{array}{c}\text { Acquisition feeding } \\
\text { period }\end{array}$ & $\begin{array}{c}\text { Days after the termination } \\
\text { of feeding }\end{array}$ & $\begin{array}{c}\text { No. of leafhoppers } \\
\text { tested }\end{array}$ & $\begin{array}{c}\text { No. of leafhoppers } \\
\text { detected by PCR }\end{array}$ \\
\hline CJW-P & 1 days & 0 days & 5 & 0 \\
& 3 & 0 & 5 & 0 \\
& & 4 & 10 & 3 \\
& & 18 & 10 & 2 \\
& & 32 & 5 & 0 \\
\hline OY-P & 42 & 10 & & 6 \\
\hline
\end{tabular}

chrysanthemum plants that had developed symptoms in the inoculation test of OY-P by $H$. sellatus. A phytoplasma-specific DNA fragment was amplified from all of the tested plants. An identically sized DNA fragment was amplified from six of the $10 \mathrm{H}$. sellatus leafhoppers maintained on the healthy garland chrysanthemum plants for 3 weeks following a 7 day acquisition feeding on OY-P infected garland chrysanthemum plants (Table 4). No phytoplasma- specific DNA fragment was amplified from any of $20 \mathrm{H}$. sellatus leafhoppers at 0 or 4 days after termination of the acquisition feeding periods on CJW-P infected C. japonica. However, the phytoplasma-specific DNA was amplified from five of 25 leafhoppers when tested between 18 and 42 days after termination of the feeding period (Table 4). These results indicated that both CJW-P and OY-P multiplied in $H$. sellatus. PCR was also performed on samples from all of the plants infected with CJW-P in the inoculation tests. The results showed that all of the plants that exhibited specific symptoms of phytoplasma infection were infected with CJW-P.

So far, one planthopper and four leafhopper species have been tested for their ability to transmit OY-P5). Seven leafhopper species $^{8)}$ have also been tested for their ability to transmit CJW-P. However, only $M$. striifrons transmitted the two phytoplasmas. The ability of $H$. sellatus to transmit OY-P and CJW-P was not tested. The results of the experiments in this paper demonstrate that OY-P and CJW-P are both transmitted by $H$. sellatus. Although $M$. striifrons-borne phytoplasmas other than OY-P and CJW-P exist in Japan, their transmissibility by $H$. sellatus remains to be determined. In these experiments, $M$. striifrons did not transmit MD-P. However, replications in the transmission tests were limited due to the difficulty in keeping $M$. striifrons alive on mulberry plants for more than 2 or 3 days to ensure the ability of $M$. striifrons to transmit MD-P. Further transmission trials may be required. This is the first report of the transmission of CJW-P and OY-P by $H$. sellatus and of the infection of garland chrysanthemum plants by MD-P.

\section{Literature cited}

1. Ikata, S. and Matsumoto, Y. (1931). Causal agents of mulberry dwarf disease. J. Silk Res. 13 : 58 (in Japanese).

2. Ishihara, T. (1965). Two new Cicadellid-species of agricultural importance (Insecta: Hemiptera). Jpn. J. Appl. Entomol. Zool. 9 : 19-22.

3. Kato, S., Shiomi, T., Wakibe, H. and Iwanami, S. (1988). Tomato yellows transmitted by the leafhopper vector, Macrosteles orientalis Virbaste. Ann. Phytopathol. Soc. Jpn. 54 : 220-223 (in Japanese).

4. Kato, S. and Iwanami, S. (1989). Occurrence of eggplant dwarf disease in Aichi Prefecture and host range of the causal MLO. Proc. Kanto-Tosan Pl. Prot. Soc. 36 : 46-49 (in Japanese).

5. Miyahara, K., Matsuzaki, M., Tanaka, K. and Sako, N. (1982). A new disease of onion caused by mycoplasmalike organism in Japan. Ann. Phytopathol. Soc. Jpn. 48 : 551-554 (in Japanese).

6. Namba, S., Kato, S., Iwanami, S., Oyaizu, H., Shiozawa, H. and Tsuchizaki, T. (1993). Detection and differentiation of plant-pathogenic mycoplasma-like organisms using polymerase chain reaction. Phytopathology 83 : 786-791.

7. Namba, S., Oyaizu, H., Kato, S., Iwanami, S. and Tsuchizaki, T. (1993). Phylogenic diversity of phytopathogenic mycoplasma-like organisms. Int. J. Syst. Bacte- 
riol. $43: 461-467$.

8. Okuda, S. and Nishimura, N. (1974). Witches' broom of Cryptotaenia japonica Hassk. Ann. Phytopathol. Soc. Jpn. 40: 439-451 (in Japanese).

9. Uehara, H. and Tsuzaki, Y. (1972). New occurrence of the lettuce yellow disease caused by mycoplasma-like microorganism in Kagawa Prefecture. Proc. Assoc. P1. Prot. Shikoku 7 : 31-34 (in Japanese).

\section{和 文 摘 要}

西村典夫・中島 智・沢柳利実・難波成任・塩見敏樹・松田 泉・土崎常男：ミツバてんぐ巣病およびタマネギ萎黄病ファイ トプラズマのヒシモンヨコバイによる伝搬
従来ヒメフタテンヨコバイにより伝搬されるとして知られて いるミツバてんぐ巣病ファイトプラズマ (CJW-P) とタマネギ 萎黄病ファイトプラズマ (OY-P) が, ヒシモンヨコバイ ( $H$. sellatus）によっても伝搬されることを明らかにした。また， CJW-P あるいは OY-P を獲得吸汁終了後 18 日以上経過した七 シモンヨコバイから PCR 法によって CJW-P あるいは OY-P がそれぞれ検出され, CJW-P および OY-Pがヒシモンヨコバイ 体内で増殖することが明らかになった。しかし，ヒシモンヨコバ イ媒介性のクワ萎縮病ファイトプラズマ (MD-P) は, ヒメフタ テンヨコバイ (M. striifrons) では伝搬されなかった。また，シ ュンギクが MD-P の宿主となることを新たに明らかにした。

(Received February 9, 1998 ; Accepted May 28, 1998) 